\title{
RETRACTED ARTICLE: Distribution characteristics of debris flows and landslides in Three Parallel Rivers Area
}

Mingtao Ding $\cdot$ Fangqiang Wei $\cdot$ Pengcheng Su $\cdot$ Huan Wang

Received: 21 April 2011/Accepted: 29 June 2011/Published online: 9 July 2011

(C) Springer Science+Business Media B.V. 2011

This article has been published OnlineFirst, but is withdrawn due to duplicate publication.

This article has been published OnlineFirst, but is withdrawn due to duplicate publication.

M. Ding $(\bowtie) \cdot H$. Wang

School of Environment and Resources, Southwest University of Science and Technology, Mianyang 621010, China

e-mail: mingtaoding@163.com

F. Wei $\cdot$ P. Su

Institute of Mountain Hazards and Environment, Chinese Academy of Sciences,

Chengdu 610041, China 